\title{
Az együttszülés feltételeinek megteremtése hazai szülészeti osztályokon a COVID-19-járvány idején
}

\author{
Lengyel Ingrid Krisztina drd. ${ }^{1}$ - Ács Nándor dr. ${ }^{2}$ \\ ${ }^{1}$ Semmelweis Egyetem, Általános Orvostudományi Kar, Magatartástudományi Intézet, Budapest \\ ${ }^{2}$ Semmelweis Egyetem, Általános Orvostudományi Kar, Szülészeti és Nőgyógyászati Klinika, Budapest
}

Bevezetés: Az Egészségügyi Világszervezet adatai alapján 2020 őszére a világ minden régióját elérte az új koronavírus (SARS-CoV-2) okozta fertőzés. Magyarországon 2020 márciusában az első esetek - több más betegjogi kérdés mellett - ráirányították a figyelmet a betegtájékoztatás kiemelt fontosságára, annak jogszabály szerinti betartására, valamint az alkalmazás során fellépő nehézségekre. Tekintve, hogy az együttszülés lehetősége az utóbbi évtizedekben egyre népszerúbb a családtervezés és a közös életkezdés folyamatában, az apák felkészítése a szülésre - a járványhelyzet miatt megváltozott tájékoztatási szigorítások összehangolásával - a szülészeti osztályok jelentős feladata lett. A betegtájékoztatás teljes körű alkalmazása során számos szempontot kellett figyelembe venni ahhoz, hogy a szülés az anya és az apa számára pozitív emlék maradjon, még olyan helyzetben is, mint a COVID-19-járvány.

Célkitüzés: Elemezni kívántuk, hogy a magyarországi szülészeti osztályokon hogyan lehetett a világjárvány idején is betartani a hatályos jogszabályokat és eljárásrendeket, milyen intézkedések váltak szükségessé az együttszülés gyakorlatának fenntartásához, és egyidejúleg biztosítani, hogy a szülőnőnek és férfi partnerének a tájékoztatáshoz való jogai ne sérüljenek.

Módszer: Online 14 feleletválogatós kérdőívet küldtünk valamennyi magyarországi, állami fenntartású kórház és klinika szülészeti osztálya vezetőjének. A beérkezett kérdőívek adatait összevetettük az intézmények honlapján az együttszüléssel kapcsolatos információkkal is.

Eredmények: A 2020. március 20. és szeptember 20. közötti fél évben a várandós párok tájékoztatása során a szolgáltatók minden esetben a hatályos eljárásrendeket követték, ez azonban több esetben többlet anyagi ráfordítást és szervezést jelentett számukra.

Következtetés: Adataink rámutatnak arra, hogy az együttszüléssel kapcsolatosan a szülésre érkezők igyekeznek a lehető legjobban tájékozódni, és ugyanolyan elvárásaik vannak a szülés körülményeit illetően, mint a járványmentes időszakban. Amennyiben a tájékoztatás kielégítő és részletes számukra, az esetleges hátrányos változtatásokat is jobban tolerálják. A járványra tekintettel valamennyi osztályon megmaradt az együttszülés lehetősége, a megfelelő járványügyi intézkedések megtartása mellett. Orv Hetil. 2021; 162(21): 824-829.

Kulcsszavak: együttszülés, betegtájékoztatás, COVID-19, eljárásrend, járványügyi intézkedések

\section{Creating conditions for male partner involvement in birth in the Hungarian obstetric wards during the COVID-19 pandemic}

\begin{abstract}
Introduction: According to data collected by the World Health Organization, by the autumn of 2020, all regions of the world were affected by SARS-CoV-2 viral infection. In Hungary, the first cases were detected in March 2020, and the epidemic, among several other patient rights issues, drew attention to the paramount importance of patient information, its compliance with the law, and the difficulties encountered in its application. During the last decades, the possibility of male partner involvement in birth has become increasingly popular in the process of family planning and starting a life together. Preparing fathers for childbirth and coordinating information restrictions that have changed due to the epidemic is a priority for obstetric departments. The full application of patient information requires a number of considerations to ensure that childbirth remains a positive memory for mother and father, even in a situation such as the COVID-19 pandemic.

Objective: We wanted to analyze how the obstetric wards in Hungary were able to comply with the laws and procedures in force at the time of the pandemic, what measures became necessary for creating male partner involvement in births, and at the same time to ensure that the rights of the mother and the father are not violated.
\end{abstract}


Method: We sent an online questionnaire to the head of the obstetrics department of all Hungarian state hospitals and clinics, using 14 multiple-choice questions. The data of the received questionnaires were also compared with the information related to male partner involvement in births published on the websites of the institutions.

Results: In the period from 20 March to 20 September 2020, in terms of informing pregnant couples, the service providers always followed the procedures in force, but in several cases this meant more financial expenditure and organization for them.

Conclusion: Our data showed that those who give birth insist on the best possible information about conditions of male partner involvement in births, have the same expectations about the conditions of childbirth as during the epidemic-free period. If the information is satisfactory and detailed for them, they are more tolerant of adverse changes. In view of the epidemic, the possibility of father involvement in birth remained in all departments available, while maintaining appropriate epidemiological measures.

Keywords: father involvement in birth, patient information, COVID-19, procedure, epidemiological measures

Lengyel IK, Ács N. [Creating conditions for male partner involvement in birth in the Hungarian obstetric wards during the COVID-19 pandemic ]. Orv Hetil. 2021; 162(21): 824-829.

(Beérkezett: 2021. február 22.; elfogadva: 2021. március 11.)

\section{Rövidítések}

COVID-19 = (coronavirus disease 2019) koronavírus-betegség 2019; PCR = (polymerase chain reaction) polimeráz-láncreakció; SARS-CoV-2 = (severe acute respiratory syndrome coronavirus 2) súlyos akut légzőszervi szindrómát okozó koronavírus-2

Az Egészségügyi Világszervezet fótitkára a 2020. március 11-én tett bejelentésében [1] pandémiának nyilvánította a SARS-CoV-2-járványt, egyben figyelmeztetett arra, hogy „eddig még sohasem láttunk olyan világjárványt, amelyet koronavírus robbantott volna ki”. Felhívta továbbá a figyelmet arra, hogy a járvány elleni küzdelemben egyes országok már kapacitáshiánytól, mások forráshiánytól szenvednek. E kapacitás- és forráshiány jól ismert probléma az egészségügyi ellátásban, hiszen nincs a világon olyan ország, ahol a nemzeti jövedelem növekedése meghaladná az egészségügyi kiadások növekedésének ütemét [2].

A szülészeti osztályokon egyre gyakrabban előforduló együttszülés igénye a hazai COVID-19-járvány első hullámában is fennmaradt. Magyarországon Marton István (MÁV Kórház, Budapest) és Szeverényi Péter (Szülészeti Klinika, Debrecen) számolt be először kedvező tapasztalatokról az együttszüléssel kapcsolatban. Bebizonyosodott, hogy a kezdeti félelmekkel szemben a megfelelő higiénés rendszabályok betartása mellett veszélytelen a férfi partner jelenléte. Az együttszülés növeli a szülőnők együttmúködési készségét, segíti a szülés zavartalan lefolyását, rövidíti a vajúdás idejét, csökkentheti a szülési szövődményeket. Az együttszülés előnyösen befolyásolja az anya-gyermek-apa kapcsolatrendszer kialakulását, fokozza, elmélyíti összetartozásukat, kedvező irányban befolyásolja a családi integráció folyamatát [3]. Az együtt- szülés lehetősége ezt követően a legtöbb hazai szülészeti osztályon elérhetővé vált a várandós párok számára.

Az előírásoknak megfelelő betegtájékoztatás a járvány idején sem mellőzhető, hiszen egyidejûleg áll fenn a látogatási tilalom és a személyes orvos-hozzátartozó találkozások hiánya. Az Emberi Erőforrások Minisztériumának állásfoglalása alapján a látogatási tilalom alól - szülés idejére - kivételt jelent a vajúdó nő kísérője. „Az apás szülésnél az apa nem látogató, hanem a szülés részese, a szülo" nô segitójje” [4]. A szülész-nőgyógyász szakma állásfoglalása is egyértelmûen támogatja a kísérő jelenlétét a szülésnél, a járvány idején is. Az Egészségügyi Szakmai Kollégium szülészet-nőgyógyászati tagozatának ajánlása [5] a COVID-19-eljárásrenddel kapcsolatban a következőt tartalmazza: „A látogatási tilalom alól egyetlen kivétel a szüléseknél az 1 fo", aki a vajúdás és a szülés során maradhat az osztály épületében." A világjárvány következtében a magyarországi kórházakban is kialakult speciális helyzet több problémára világított rá. Nyilvánosságra került, hogy az egyes szülészeti intézmények eltérô módon reagáltak az elrendelt látogatási tilalomra, ez a közösségi médiában és a szakfelügyeleti rendszer felé is megfogalmazott, helyenként felháborodott véleménynyilvánítást eredményezett. Vizsgálatunk célja annak felmérése volt, hogy a pandémia által kiváltott helyzetben Magyarország egyes szülészeti intézményeiben hogyan biztosították az együttszülés lehetőségét és feltételeit, valamint hogyan alakult a betegtájékoztatás megfelelösége.

\section{Módszer}

A COVID-19-járvány első hulláma idején zajlott szülésekhez kapcsolódó információkat 14 kérdéses online kérdőívben kértük a magyarországi, állami fenntartású kórházak és klinikák szülészeti osztályainak vezetőitől. 
A kérdőív kialakítása során figyelembe vettük a kollégák járvány miatti rendkívüli leterheltségét, ennek megfelelően igyekeztünk a legkevesebb időráfordítást igénylő válaszokat kérni (egyszerü feleletválogatós és két, szabad szövegezésű kérdés). Az adott válaszok feldolgozásával betekintést kívántunk kapni a 2020. március 20. és 2020. szeptember 20. közötti időszak együttszülésekkel kapcsolatos változásairól, a megtett intézkedésekről, amelyek a betegtájékoztatás és a panaszmentes ellátás érdekében történtek. Tematikus bontás szerint négy kérdés a betegek, a hozzátartozók és a dolgozók tájékoztatására, két kérdés a felmerülő többletköltségekre és betegjogi panaszokra, a fennmaradó kérdések pedig az esetleges szakmai irányelvi változásokra vonatkoztak. A beérkezett kérdöívek válaszait összevetettük az intézmények honlapján, Facebook-oldalain található, együttszüléssel kapcsolatos információkkal is. Az intézményi tájékoztatás során azt is vizsgáltuk, hogy az érintett dolgozók irányában történt-e kríziskommunikáció, s ha igen, milyen formában. Jelen rövid felmérésünk kizárólag arra irányult, hogy egy megváltozott, eddig nem ismert helyzetben jelentkező kihívásokra betekintést adjon, amely később alapját képezheti szakmai ajánlások elkészítésének és egyéb racionális válságintézkedéseknek.

\section{Eredmények}

A kiküldött 78 kérdőívból 41 (60,3\%) érkezett vissza kitöltve a megadott határidőre. A választ adó szülészeti intézmények földrajzi megoszlását az 1. táblázatban foglaltuk össze.

A 2020. március 20. és 2020. szeptember 20. közötti időszakban (a kérdőívet kitöltő szülészeti osztályokon) 25176 szülést regisztráltak. Az adatok megoszlását a klinikák és kórházak, valamint a vidék és a fóváros viszonylatában vizsgáltuk (1. ábra).

A Központi Statisztikai Hivatal adatközlése alapján 2020-ban 92233 szülés történt Magyarországon. Figyelembe véve, hogy az általunk vizsgált szülésszám hat hónap alatt 25176 volt, ez azt jelenti, hogy felmérésünk a szülések valamivel több mint felére (kb. $55 \%$-ára) vonatkozott. A 2. táblázatban azt vizsgáltuk, hogy változott-e a COVID-járvány idején a vizsgált időszakban az együttszülés iránti igény az egyes intézményekben.

Négy vidéki intézmény jelezte, hogy náluk ebben az időszakban (szülések száma: 2390) nem volt lehetőség együttszülésre. Összehasonlítva a kérdőív válaszait a honlapon megjelenő információkkal, a négy kórházból egy semmiféle említést nem tesz, három kórház egyetlen mondatban említi az együttszülés lehetőségét osztályukon. A fóvárosi és a vidéki klinikák által adott válaszok eredményeit összevetve az igen válaszok tekintetében hat, a nemleges válaszok esetében öt egyezés tapasztalható.

A COVID-19-járvány időszakában a válaszadó intézmények több mint fele (61\%) új eljárásrendet készített az együttszülésekkel kapcsolatosan. Ezek kivonataiból be-
1. táblázat |A kitöltött kérdőívek földrajzi megoszlása $(\mathrm{n}=4 \mathrm{l})$

\begin{tabular}{lcc}
\hline Főváros/Vidék & Az intézmények jellege & Az intézmények száma \\
\hline Budapest & Klinika & 2 \\
& Kórház & 7 \\
\hline Vidék (összesen) & Klinika & 2 \\
& Kórház & 30 \\
\hline
\end{tabular}

2. táblázat |Változott-e az együttszülés iránti igények száma? $(\mathrm{n}=41)$

\begin{tabular}{lccc}
\hline Főváros/Vidék & $\begin{array}{c}\text { Az intézmények } \\
\text { száma összesen }\end{array}$ & A válasz jellege & $\begin{array}{c}\text { Az intézmények } \\
\text { száma }\end{array}$ \\
\hline Budapest & 9 & Igen & 2 \\
& & Nem & 7 \\
\hline Vidék (összesen) & 32 & Igen & 1 \\
& & Nem & 31 \\
\hline
\end{tabular}

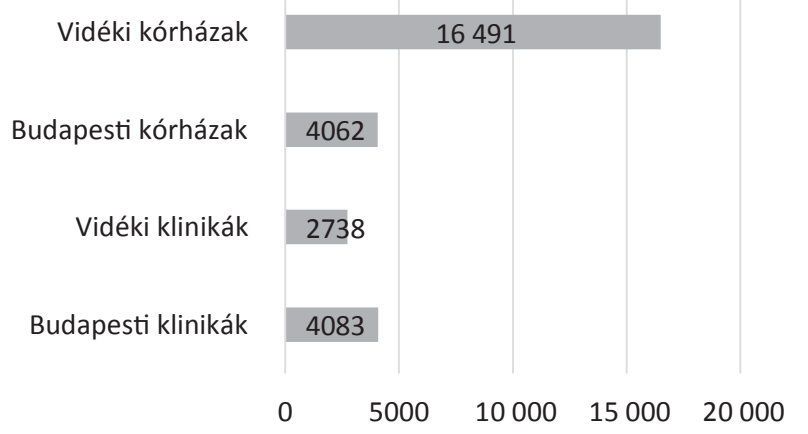

1. ábra $\mid$ A szülések száma a vizsgált időszakban a válaszadók közlése alapján $(\mathrm{n}=25$ 176)

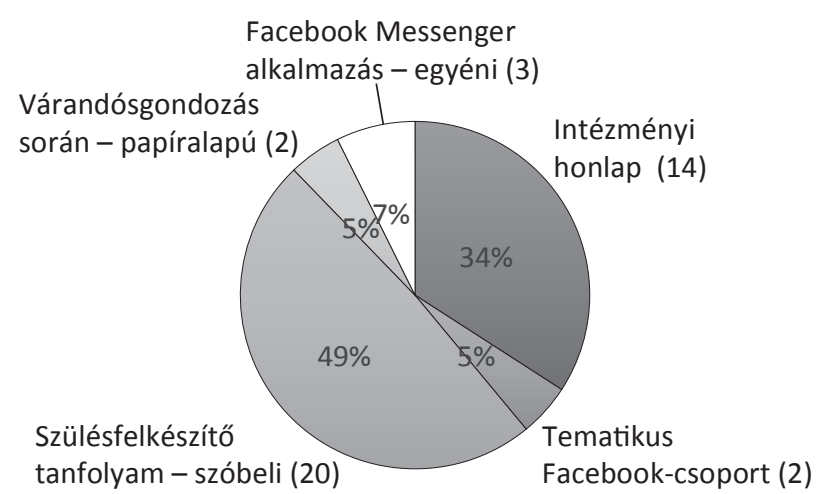

2. ábra $\mid$ A betegtájékoztatás módjai és megoszlása az intézménynél az együttszülésekkel kapcsolatosan $(n=41)$

tegtájékoztatók készültek, majd kerültek közzétételre. A betegtájékoztatás 14 esetben történt az intézményi honlapokon, két kórház esetében egy erre a célra létrehozott Facebook-csoporton belül tájékoztatták a várandós párokat. Két esetben a várandósgondozáson papíralapú tájékoztatás, húsz esetben a szülésfelkészítő 
3. táblázat $\mid$ A szülés utáni hazabocsátás napjának változása a fơvárosi és a vidéki kórházakban $(\mathrm{n}=4 \mathrm{l})$

\begin{tabular}{lcc}
\hline & $\begin{array}{c}\text { IGEN, a szülés } \\
\text { után lerövidült } \\
\text { a kórházi } \\
\text { tartózkodás ideje } \\
\text { (napokban) }\end{array}$ & $\begin{array}{c}\text { NEM változott } \\
\text { a szülés utáni } \\
\text { kórházi } \\
\text { tartózkodás ideje } \\
\text { (napokban) }\end{array}$ \\
\hline Budapesti kórházak, klinikák & 5 & 4 \\
Vidéki kórházak, klinikák & 6 & 26 \\
\hline Összesen & 11 & 30 \\
\hline
\end{tabular}

tanfolyamon szóban, míg három esetben egyéniesített formában, a várandós Facebook Messenger üzeneti lehetőségét használva ismertették az együttszülés lehetőségét a várandósokkal (2. ábra).

A megváltozott klinikai és kórházi eljárásrendeknek, szabályoknak a dolgozókkal való megismertetése a fóvárosi intézményekben hiánytalanul megtörtént, míg erre a többi kórház 75\%-ában volt mód. A megnövekedett betegtájékoztatási igény az intézmények jelentős részének (35 osztály) nem jelentett többletköltséget. A megkérdezettek szerint a vizsgált időszakban érkezett az együttszülésekhez köthető néhány betegjogi panasz, de ennek számszerűségéről nem nyilatkoztak.

A császármetszésnél való apai jelenlétet illetően mind a négy válaszadó klinikán bent lehetett az apa a mütőben, míg 26 kórházban ezt nem engedélyezték. Két kórház megengedte, hogy az apa a mútő előterében tartózkodjék. A gyermekágyas látogatás tilalma a hatályos eljárásrendnek megfelelően országosan egységes volt.

$\mathrm{Az}$ első hullámban valamennyi megkérdezett intézmény közül két szülészeti osztály kért negatív PCR-tesztet, a járvány második hullámában már az együttszülés feltétele volt a 72 órán belül készült negatív PCR-teszt. A két fơvárosi klinikán és két kórházban kötelező, míg öt helyen ajánlott volt a negatív teszteredmény bemutatása. A vidéki két klinikán és a 30 vidéki kórház közül 22-ben kötelező jelleggel, míg a többi helyen ajánlottan kellett a teszteredményt felmutatni.

A rövid felmérés végén a COVID-19-járvány idején zajlott szülések kapcsán azt is vizsgáltuk, hogy a járványügyi érdekeket szem előtt tartva lerövidíthető-e a kórházi tartózkodás ideje; ennek eredményeit a 3. táblázat mutatja be.

Lehetőség volt észrevételek megfogalmazására is: két vidéki kórház jelezte, hogy az eljárásrendeknek eleget téve, a védőöltözetet biztosítva, megfelelő tájékoztatással és egy negatív COVID-teszt birtokában lehetett jelen az apa a szülés alatt mindkét járványperiódusban.

\section{Megbeszélés}

$\mathrm{Az}$ együttszülés története, nem számítva az évezredes hagyományt, az elmúlt évszázad utolsó évtizedeiben kapott lendületet [6]. 1960 elött az apát „kényelmetlenségnek" tekintették a szülőszobán, aki adott esetben ve- szélyeztetheti a szülőnő ellátását, és esetenként el is ájulhat. Később nyilvánvalóvá vált, hogy az apának helye van a szülésnél, és ennek népszerüsítésére szülésfelkészítő tanfolyamokat indítottak. Ismert olyan álláspont is [7], amely szerint az apának nincs helye az egészségügy rendszerében. Más szerzők szerint az a fontos, hogy az apa felkészülhessen, és gyakorolhasson a szerepére $[8$, 9]. Igazolták, hogy a várandósság és a szülés ideje alatt az apa több érzelmet él át: eufóriát, boldogságot, sokkot és szorongást [10]. Leírják azt is, hogy az apa hogyan alakítja viselkedését partnere támogatása érdekében. Ezt két további tanulmány is megerősíti $[11,12]$, amelyekből kiderül, hogy az apa aktív részvételének szándékát tiszteletben kell tartani a szülés során, és lehetőség szerint hozzá kell járulni ehhez. Ebben a küldetésben az egészségügyi szakemberek részéről az apának támogatásra van szüksége.

Kelet-közép-európai kultúránkban az apa korábban ki volt rekesztve a szülésból, azt nói dolognak tartották, ahol a férfinak nem volt helye. A kórházi szülések elterjedésével az apa a folyosón várakozhatott. Az apa szülőszobához való közelségét számos sztereotípia jellemezte, például az, hogy az apa a szülés látványától elájul, és őt kell ellátni, miközben az anya vajúdik. Később az, hogy az apa jelen legyen-e a szülésnél, számos vita tárgyát képezte. Az ellenzők azzal érveltek, hogy a szülés élménye negatívan hat a párkapcsolatra. Hazánkban az 1980-as évek elejétől juthatnak be az apák a szülőszobára, és élhetik át testközelből gyermekük születését. A rendszer bevezetése fokozatos volt, eleinte nem lehetett minden kórházban az apa jelenlétében szülni. Eleinte a „papás szülés”, „apás szülés” terminológiával illették az új jelenséget, Magyarországon ez egy szép új kifejezéssel, az együttszüléssel cserélődött fel. Ez a terminológia mára megváltozott, és az „apás szülés” a legelterjedtebb megfogalmazás. Franciaországban Lamaze elsőként ismerte fel a szociális környezet jelentőségét: az apákat bevonta a felkészítésbe, melynek során a szülőnő állandó biztatást, segítséget, lelki nyugalmat kap a párjától. A megfelelően felkészült partner biztos érzelmi támaszt nyújt társának. Jelenléte megnyugtató, megszünteti az elhagyottság, kiszolgáltatottság érzését, csökkenti a szorongást, félelmet, elviselhetőbbé teszi a szülési megpróbáltatásokat.

Budapesten, a Róbert Károly Körúti Kórházban 1985től lehettek bent az édesapák a szülésnél. Abban az évben az apák húsz százaléka élt ezzel a lehetőséggel, és egy év alatt 100 ilyen szülés zajlott le, koraszülés nélkül. Érdemi áttörést e területen hazánkban a Papp Zoltán professzor által 1992-ben alapított Magyar Pszichoszomatikus Szülészeti és Nőgyógyászati Társaság tevékenysége jelentett. Azóta az apák jelenléte a szülésnél a magyar szülészeti osztályokon teljesen természetes, az újszülöttet azonnal odaadják az édesapának is. $\mathrm{Az}$ együttszülés olyan lehetőséget jelent, amely kedvezően befolyásolhatja az anya-gyermek-apa kapcsolati rendszert, és a rendszer mindhárom összetevőjére pozitív hatása lehet $[13,14]$. 
Pandémia idején a védekezés befolyásolhatja a betegjogok teljesülését, így a veszélyhelyzetre tekintettel az egészségügyben is korlátozó intézkedéseket vezettek be, például a kórházban kezelt betegek látogatási tilalmát. Fontos tudni azonban, hogy a szakmai és minisztériumi utasítások alapján a szülőnő kísérőjére nem vonatkozik ez a korlátozás. Az egészségügyről szóló 1997. évi CLIV.

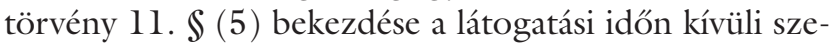
mélyes kapcsolattartási jogot állapít meg, mely szerint a szülőnőnek joga van arra, hogy az általa megjelölt nagykorú személy a vajúdás és a szülés alatt folyamatosan vele lehessen, a szülést követően pedig arra, hogy - amennyiben ezt az ő vagy újszülöttje egészségi állapota nem zárja ki - újszülöttjével egy helyiségben helyezzék el.

A vizsgált időszakban a kórházak meghatározhatták, hogy a szülőnőt kísérő apán kívül engednek-e még be más kísérôt (közeli családtag, dúla), vagy kizárólag az apa lehet jelen. Az alaptörvényben foglaltak - mint az élethez és az emberi méltósághoz való jog gyakorlása rendkívüli helyzetben - járványidőszakban sem függeszthető fel, és a korlátozás mértéke is csak a szükséges és arányos szintig engedhető meg. Az apának kötelessége a fertőzés terjedésének megakadályozása érdekében az intézmények által előírt intézkedésekben együttmúködni. $\mathrm{Az}$ alaptörvényből vezethetők le a betegjogok is, így azok gyakorlása - az említett időszakban - kiemelt figyelmet kíván. Megfelelő szabályozással és az érintettek tájékoztatásával minimálisra csökkenthetők a betegek/ hozzátartozók részéről megfogalmazott panaszok.

A betegek megfelelő tájékoztatása önrendelkezési joguk érvényesülésének alapvető és elengedhetetlen feltételét képezi. A kommunikációra vonatkozó paragrafusok (érthetően) jobbára a szakmai, tartalmi elemekre fókuszálnak. Egyéb kapcsolódó jogszabályok, intézményi belső utasítások, minőségügyi eljárásrendek, panaszkezelési szabályzat, munkaköri leírások és szakmai ajánlások a jogszabályi hierarchia betartásával készülnek.

A betegnek joga van arra, hogy számára érthető módon kapjon tájékoztatást, figyelemmel életkorára, iskolázottságára, ismereteire, lelkiállapotára, e tekintetben megfogalmazott kívánságára, valamint arra, hogy a tájékoztatáshoz szükség esetén és lehetôség szerint tolmácsot vagy jelnyelvi tolmácsot biztosítsanak...” [15].

A betegek és hozzátartozóik betegjogi tudatossága a fóvárosban kimagasló értékeket mutat [16]. A legtöbb panaszolt esetben a betegek nem kaptak személyre szabott formában történő és teljes körü tájékoztatást. Gyakran előfordult, hogy az orvossal való megbeszélés során vagy azt követően nem mertek további kérdéseket feltenni az adott tájékoztatással kapcsolatban. A tájékoztatáshoz való jog hiányos megvalósulása többnyire kis számban szerepelt önálló sérelemként a betegjogi képviselői megkeresések között, a legtöbb esetben azonban valamilyen módon kapcsolódott más, betegjogot érintő panaszokhoz. A jogvédelmi képviselők számos esetben tapasztalták, hogy az ún. nem orvosszakmai tárgyú betegpanaszok száma jelentősen csökkenthetővé válhatna, amennyiben az orvos/ápoló-beteg bizalmi viszonyban felmerülő kommunikáció javulhatna [17]. Azok az esetek, amikor a beteg nem kap megfelelő tájékoztatást, információt, közvetve kihatnak a beteg további egészségi állapotára, és olykor újabb egészségügyi szolgáltatás igénybevételére késztetik a beteget. Pandémia idején a tájékoztatásra vonatkozó megnövekedett igény a beteg és a hozzátartozó részéről érthető és elfogadható.

Gyakoriak a szolgáltatók betegtájékoztatási hiányosságai [18], de az ellátó- és finanszírozási rendszer sem ösztönzi a kezelőorvost abban, hogy kimerítően magyarázzon egy információra éhes betegnek a betegségéról, a választási lehetőségeiről, valamint a lehetséges szövődményekről.

Tapasztalatunk alapján a felmérés során eltérések mutatkoztak a honlapokon történő tájékoztatás tekintetében. A tájékoztatás tartalma és annak értelmezése a felhasználó feladata. Ebben a kérdéskörben nem mutatkozott az a jelenség, hogy a várandós párok ne tájékozódtak volna előzetesen az internetról, vagy ne lett volna hozzáférésük a netes felületekhez. Az együttszülésekkel kapcsolatba hozható betegjogi panaszok esetében a kórházak mutattak javítani való állapotokat, a fővárosi és vidéki klinikákon csak a tény került feltárásra, a számszerüsége nem.

Elgondolkodtató, hogy egy esetben aggályát fejezte ki az egyik vidéki kisváros szülészeti osztályának vezetője, a járvány idején is „kötelezően biztosítandó” együttszülés lehetőségével kapcsolatosan.

A COVID-19-járvány alatt elvégzett felmérés eredményei rámutattak arra, hogy az együttszülés lehetősége kiemelten fontos a családok számára, nem szokványos körülmények között is. Ennek biztosításához a hatályos betegjogok - ezen belül kiemelten a tájékoztatáshoz való jog - megfelelő és naprakész ismerete és ismertetése szükséges. A szülészeti szolgáltatók felelőssége, hogy milyen kommunikációs eszközöket vesznek igénybe a várandósok és hozzátartozóik tájékoztatásához, és azt milyen gyakorisággal aktualizálják.

\section{Következtetés}

A hazai egészségügyi rendszerben, ha az ellátó minden paragrafusra kiemelt figyelmet és elégséges időt fordítana, a rendszer múködőképessége labilissá válna. Így az áthidaló és elégséges megoldást az jelentheti, hogy a beteg állapotára fókuszálva, a rövid távú célokat és tervezett eljárásokat, terápiákat szem előtt tartva szükséges a minimuminformációt a betegnek átadni. Ezt nem befolyásolhatja egy járványhelyzet sem. Az intézmények egy részének a váratlan helyzethez való információs alkalmazkodás többletköltséget jelenthet, erre azonban bármely időszakban fel kell készülni.

A járványt megelőző időszakban valamennyi hazai szülészeti osztályon biztosították az együttszülés feltételeit. Ez az arány a járvány idején sem változott. Ugyanakkor erre az adott lehetőséget, hogy a szigorú járvány- 
ügyi elöírásokat minden tekintetben igyekeztek az osztályok betartani. A járványra tekintettel egy osztályon sem vonták vissza az együttszülés lehetőségét, ezzel is biztosítva a társas támaszt a szülőnook számára a járványból adódó különösen nehéz helyzetekben is.

Anyagi támogatás: A közlemény megírása anyagi támogatásban nem részesült.

Szerzői munkamegosztás: L. I. K.: A kérdőívek összeállítása, az elemzések elkészítése, kutatásfeldolgozás, irodalomkutatás. Á. N.: Az országos adatok validitásának jóváhagyása, a kézirat orvosi megfelelőségének revíziója. A cikk végleges változatát mindkét szerző elolvasta és jóváhagyta.

Érdekeltségek: A szerzőknek nincsenek érdekeltségeik.

\section{Köszönetnyilvánítás}

Köszönetet mondunk az adatszolgáltatásban részt vevő klinikák és kórházi osztályok professzorainak és osztályvezető főorvosainak.

\section{Irodalom}

[1] World Health Organization. WHO Director-General's opening remarks at the media briefing on COVID-19 - 11 March, 2020. Available from: https://www.who.int/director-general/speeches/detail/who-director-general-s-opening-remarks-at-the-media-briefing-on-covid-19---11-march-2020 [accessed: November 15,2020$]$.

[2] Mozsár F. Resource allocation in the health care industry. In: Lengyel I. (ed.) Growth and development of regions: health industrial and knowledge-based development strategies. [Az egészségügyben felhasznált erőforrások allokációja. In: Lengyel I. (szerk.) Térségek növekedése és fejlődése: egészségipari és tudásalapú fejlesztési stratégiák.] Szegedi Tudományegyetem, Gazdaságtudományi Kar, JATEPress, Szeged, 2018; pp. 136150. [Hungarian]

[3] Hagymásy L. (ed.) Family-oriented obstetrics. [Családközpontú szülészet.] Signatura Kiadó, Nyíregyháza, 1994. [Hungarian]

[4] Kásler M. Ministerial instruction of the minister for human resources to the heads of all inpatient care institutions. (Subject: Instruction to obstetrics - paternal birth; Date: 21/03/2020.) [Az emberi erőforrások miniszterének IV/2676/2020/EAT ikt. sz. miniszteri utasítása valamennyi fekvőbeteg-ellátó intézmény vezetőjének. (Tárgy: Szülészetek részére küldendő utasítás - apás szülés; Kelt: 2020. március 21-én.)] Emberi Erőforrások Minisztériuma, Budapest. [Hungarian]

[5] Ministry of Human Capacities. Recommendation of the Fraction of Obstetrics and Gynecology and Assisted Reproduction of the College of Health in connection with the COVID-19 care. (Effective: 21 March, 2020.) [Az EMMI Egészségügyi Szakmai Kollégium Szülészeti-Nőgyógyászati és Asszisztált Reprodukciós Tagozat ajánlása a COVID-19 ellátásrenddel kapcsolatosan.
(Hatályos: 2020. március 21-tól.)] Emberi Erőforrások Minisztériuma, Budapest. Available from: https://kollegium.aeek.hu/ Dokumentumok/Index/eljárásrendek. [Hungarian]

[6] Ledenfors A, Berterö C. First-time fathers' experiences of normal childbirth. Midwifery 2016; 40: 26-31.

[7] Steen M, Downe S, Bamford N, et al. Not-patient and not-visitor: a metasynthesis of fathers' encounters with pregnancy, birth and maternity care. Midwifery 2012; 28: 422-431.

[8] Chandler S, Field PA. Becoming a father. First-time fathers' experience of labor and delivery. J Nurse Midwifery 1997; 42: $17-24$.

[9] Dellmann T. The best moment of my life: a literature review of fathers' experience of childbirth. Aust Midwifery 2004; 17: 2026.

[10] Poh HL, Koh SS, Seow HC, et al. First-time fathers' experiences and needs during pregnancy and childbirth: a descriptive qualitative study. Midwifery 2014; 30: 779-787.

[11] Johansson M, Fenwick J, Premberg A. A meta-synthesis of fathers' experiences of their partner's labour and the birth of their baby. Midwifery 2015; 31: 9-18.

[12] Vehviläinen-Julkunen K, Liukkonen A. Fathers' experiences of childbirth. Midwifery 1998; 14: 10-17.

[13] Szeverényi P, Hetey A, Forgács A, et al. Preparing for birth together. [Felkészülés az együttszülésre.] Magy Nőorv L. 1990; 53: 343-346. [Hungarian]

[14] Szeverényi P. The history of the psychosomatics of obstetrics and gynecology in Hungary. The activity of the Hungarian Society of Obstetrical and Gynecological Psychosomatics (MAPSZIG). [A szülészet-nőgyógyászati pszichoszomatika története Magyarországon. A Magyar Pszichoszomatikus Szülészeti és Nőgyógyászati Társaság (MAPSZIG) tevékenysége.] Magy Nőorv L. 2020; 83: 230-237. [Hungarian]

[15] Section 13 of Parliamentary Act No. CLIV of 1997 on Health Care. [Az egészségügyrôl szóló 1997. évi CLIV. törvény 13. \$-a.] Available from: https://net.jogtar.hu/jogszabaly?docid $=99700154 . t v$ [valid from: 15 Nov, 2020]. [Hungarian]

[16] Annual activity report of National Centre for Patients' Rights and Documentation of 2018. In: 2018 professional report. [Az Integrált Jogvédelmi Szolgálat (IJSZ) 2018. évi szakmai beszámolója. p. 25.] Emberi Erőforrások Minisztériuma, Budapest, 2018. Available from: http://www.ijsz.hu/UserFiles/ beszamolo_2018.pdf [accessed: November 16, 2020]. [Hungarian]

[17] Annual activity report of National Centre for Patients' Rights and Documentation of 2018. In: 2018 professional report. [Az Integrált Jogvédelmi Szolgálat (IJSZ) 2018. évi szakmai beszámolója. p. 29.] Emberi Erőforrások Minisztériuma, Budapest, 2018. Available from: http://www.ijsz.hu/UserFiles/ beszamolo_2018.pdf [accessed: November 16, 2020]. [Hungarian]

[18] Annual activity report of National Centre for Patients' Rights and Documentation of 2014. In: 2014 professional report. [Az Országos Betegjogi, Ellátottjogi, Gyermekjogi és Dokumentációs Központ (OBDK) 2014. évi szakmai beszámolója.] Available from: http://www.obdk.hu/UserFiles/beszamolo_2014. pdf [accessed: November 16, 2020]. [Hungarian]

(Lengyel Ingrid,

Budapest, Jókai u. 12., 1195 e-mail: lengyel.ingrid@gmail.com)

A cikk a Creative Commons Attribution 4.0 International License (https://creativecommons.org/licenses/by/4.0/) feltételei szerint publikált Open Access közlemény, melynek szellemében a cikk bármilyen médiumban szabadon felhasználható, megosztható és újraközölhető, feltéve, hogy az eredeti szerző és a közlés helye, illetve a CC License linkje és az esetlegesen végrehajtott módositások feltüntetésre kerülnek. (SID_1) 